\title{
ANALISIS TEKNO-EKONOMI LAMINASI KAPAL PSP 01 DI PALABUHAN RATU, JAWA BARAT
}

\author{
Techno-Economy Analisys of PSP 01 Boat Lamination In Palabuhan Ratu, West Java
}

Oleh:

\author{
Mohammad Imron ${ }^{1}$, Deni Achmad Soeboer ${ }^{2}$, Rahmad Ramadhoni ${ }^{3}$ \\ ${ }^{1}$ Staf Pengajar Departemen PSP-FPIK-IPB \\ 2 Staf Pengajar Pascasarjana TPL-Dep PSP-FPIK-IPB \\ ${ }^{3}$ Mahasiswa Program Studi Teknologi dan Manajemen Perikanan Tangkap \\ Korespondensi: denisoeboer@gmail.com
}

\begin{abstract}
ABSTRAK
Laminasi kapal adalah proses pelapisan kapal kayu dengan menggunakan FRP, yang bertujuan untuk memperbaiki, memperkuat, mencegah kebocoran, dan menambah umur teknis kapal. Penelitian ini bertujuan untuk mendeskripsikan teknik laminasi kapal PSP 01, membuat formulasi untuk menghitung kebutuhan bahan laminasi kapal, dan menghitung biaya proses laminasi kapal PSP 01. Hasil penelitian menunjukkan bahwa proses laminasi kapal terdiri atas 3 tahapan utama yakni pendempulan, pelapisan FRP, dan pengecatan. Berdasarkan hasil perhitungan dan pengolahan data hasil laminasi, didapatkan formula untuk menghitung kebutuhan lembar fiberglass non overlay (Tln) = Luas badan kapal/1,2 meter, formula untuk menghitung lembar fiberglass overlay (Tloverlay) $=($ $($ Tln - 1) x 0,44 m ) / 1,2 m. Rumus yang digunakan untuk menghitung total kebutuhan lembar fiberglass (Tlfix) $=\mathrm{Tln}+$ Tloverlay. Berdasarkan hasil perhitungan jumlah resin, didapatkan rata-rata resin dipakai (NSKB) sebesar $1099,27 \mathrm{~cm}^{3}$ perlembar fiberglass, sehingga dapat diaplikasikan untuk menghitung jumlah kebutuhan resin total (TBresin) resin dengan rumus $=$ (NSKB resin $\mathrm{x}$ Tlfix). Total kebutuhan katalis dapat dihitung dengan mengalikan total kebutuhan resin dengan nilai standar $2 \%$. Total biaya yang dipakai untuk laminasi kapal PSP 01 adalah Rp 11.851.000.
\end{abstract}

Kata kunci : fiberglass, kapal, laminasi, PSP 01.

\section{ABSTRACT}

Boat lamination was a coating process of wooden boat using fibreglass reinforced plastic which aims to improve the strength, prevent the leakage, and improve the technical life of the boat. This reseacrh aims to describe the lamination technique of PSP 01 boat, calculate the lamination's material need, and calculate the cost of PSP 01 boat lamination process. The results of research showed that the ship lamination process consists of three main stages such as body repair, FRP coating, and painting. Based on calculations and data processing results, were found a formula to calculate the non-overlay fiberglass sheets need (Tln) = large of ship body / 1.2 meters, the formula for calculate the fiberglass overlay sheet need (Tloverlay) $=((T l n-1) \times 0,44 \mathrm{~m}) / 1.2$ meters $)$, and The formula that used to calculate the total of fiberglass sheets need (Tlfix) $=$ Tln + Tloverlay. Based on the use of resin, are found the value of resin need $(N S K B)=1099.27 \mathrm{~cm} 3$ per sheet of fiberglass, so it can be applied to calculate the total amount of resin needs (TBresin) using the formula $=($ TIfix $x$ NSKB resin). The need of catalis can be found by using the formula = (need of resin $x 2 \%)$. Total cost that used for PSP 01 boat lamination is $R p$ 11.851.000.

Keywords: Boat, fibreglass, lamination, PSP 01. 


\section{PENDAHULUAN}

Perkembangan ilmu dan pengetahuan tentang teknologi pembuatan kapal saat ini sudah terjadi dengan pesat. Hal ini dapat dilihat dari perubahan dan perkembangan penggunaan bahan baku pembuatan kapal yang semakin baik. Kayu yang dahulu menjadi salah satu bahan utama pembuatan kapal namun kini mulai banyak digantikan, karena semakin langkanya kayu dan dianggap mengganggu kelestarian hutan serta membuka peluang ilegal logging. Bahan kayu mulai digantikan dengan bahan jenis besi. Bahan jenis besi dipilih karena memiliki konstruksi yang sangat kuat, sehingga sangat aman dan efektif didalam pengoperasiannya. Kelemahan dari kapal berbahan besi adalah bahan bakunya sangat mahal dan mengalami proses pengkaratan (korosi), sehingga ada keterbatasan dalam umur teknisnya. Mengingat akan hal tersebut, kemudian diciptakan kapal dengan bahan baku FRP (fibreglass reinforced plastic)(Anwar, 2010). Kapal dengan bahan FRP memiliki beberapa keunggulan bila dibandingkan dengan bahan baku lain, diantaranya tahan terhadap benturan (elastisitas tinggi), tidak mengalami korosi, bahan baku ringan dan mudah didapat dengan harga terjangkau, umur teknis kapal lebih panjang/lama (Nurcahyadi Moh, 2010).

Teknologi penggunaan bahan FRP ini juga dapat diaplikasikan untuk perbaikan dan pembuatan kapal kayu. Salah satu teknologi penggunaan FRP pada kapal kayu yang mulai banyak dikenal adalah dengan cara laminasi kapal. Laminasi kapal adalah proses pelapisan badan kapal kayu dengan menggunakan FRP, yang bertujuan untuk memperbaiki, memperkuat, menutup kebocoran, dan meningkatkan umur teknis kapal (Wave Train, 2011). Laminasi kapal banyak dipilih oleh para pemilik kapal kayu untuk menambah umur teknis karena biaya laminasi yang semakin terjangkau. Selain itu, proses laminasi terbukti sangat baik dan teruji bagi kapal perikanan berbahan kayu setelah dilaminasi dapat menambah umur teknis dan mengurangi biaya perawatan kapal. Saat ini banyak pengusaha perikanan yang memiliki unit kapal penangkap ikan berbahan kayu mulai melakukan laminasi terhadap kapal-kapalnya.

Pengerjaan laminasi kapal juga sudah banyak dikuasai oleh pekerja tradisional, sehingga laminasi kapal kayu dapat dilakukan dimanapun. Namun didalam pengerjaannya para pekerja tradisional hanya menggunakan metode kira-kira baik penentuan jumlah bahan yang dibutuhkan maupun metode laminasi yang digunakan. Sehingga proses pengerjaan laminasi kapal menjadi kurang efektif dan efisien juga dalam memperkirakan biaya dan waktu pengerjaan. Karena ketidakpahaman dalam menganalisis pengerjaan laminasi kapal baik pengusaha perikanan maupun pekerjanya maka dapat menyebabkan proses laminasi kapal menjadi tidak efisien, baik dari segi waktu maupun biaya. Berdasarkan hal tersebut, penelitian mengenai analisis tekno-ekonomi laminasi pada kapal PSP-01 ini sangatlah penting untuk meningkatkan efisiensi didalam proses laminasi kapal, sehingga dapat menjadi acuan bagi para pengusaha perikanan yang akan melakukan laminasi dapat menentukan biaya, jumlah alat dan bahan yang dibutuhkan serta lamanya pengerjaan. Adapun tujuan dari penelitian ini adalah mengkaji proses laminasi kapal PSP 01, membuat formulasi kebutuhan alat dan bahan untuk laminasi per satuan luas (meter persegi) badan kapal, serta menghitung biaya proses laminasi kapal PSP 01.

\section{METODOLOGI PENELITIAN}

Penelitian ini dilaksanakan di area doking Pelabuhan Perikanan Nusantara Palabuhanratu, peralatan yang digunakan dalam penelitian ini seperti disajikan pada Tabel 1 berikut ini: 
Tabel 1. Daftar peralatan yang digunakan

\begin{tabular}{ll}
\hline \multicolumn{1}{c}{ Alat dan Bahan } & \multicolumn{1}{c}{ Fungsi } \\
\hline Alat ukur (penggaris \& meteran) & $\begin{array}{l}\text { Mengukur ukuran dan volume alat serta bahan yang } \\
\text { dipakai dalam laminasi. } \\
\text { Alat bantu hitung untuk penjumlahan bahan } \\
\text { Kalkulator }\end{array}$ \\
laminasi dilapang serta analisis data. \\
Tali rafia & Alat bantu untuk mengukur alat dan bahan laminasi. \\
Alat tulis & Mencatat semua data yang dibutuhan. \\
Kamera & Mendokumentasikan proses laminasi. \\
Software Corel X4 & Membuat proyeksi gambar kapal 2 dimensi. \\
Microsoft Excel & Mengolah data. \\
Software maxsurf & Menghitung luas badan kapal \\
Google Sketchup & Memuat proyeksi gambar kapal 3 dimensi. \\
\hline
\end{tabular}

Metode penelitian yang digunakan dalam penelitian ini adalah Observasi langsung, dengan obyek yang diteliti yaitu KM PSP 01. Metode ini digunakan untuk memberikan gambaran secara detail tentang teknik, tahapan, dan biaya dari proses laminasi kapal PSP 01.

\section{Pengumpulan Data}

Berdasarkan jenisnya, jenis data yang diambil terdiri dari data primer dan sekunder :

1) Data primer pada penelitian ini terdiri atas material laminasi, tahapan dan teknik laminasi, kebutuhan bahan per satuan luas (meter) badan kapal, waktu pengerjaan dan tempat laminasi, serta biaya laminasi. Data tersebut didapat melalui observasi, wawancara, dan pengukuran langsung proses laminasi. Data mengenai harga alat dan bahan yang dibutuhkan diperoleh dari toko penjual bahan fibreglass.

2) Data sekunder yang digunakan pada penelitian ini adalah data mengenai desain dan konstruksi kapal PSP 01 untuk mengetahui luasan badan kapal, standar penggunaan bahan, dan metode standar pengerjaan pembuatan kapal FRP oleh FAO. Data ini diperoleh dari buku training manual on construction of FRP beach landing boats yang diterbitkan oleh FAO, serta literatur lain yang berkaitan dengan penelitian ini.

\section{Pengolahan dan Analisis Data}

Data yang telah diperoleh diolah dengan cara merangkum hasil wawancara dan observasi di lapangan, mentabulasikan hasil pengukuran, menggambarkan proses laminasi, dan mentabulasikan daftar barang serta serta biaya yang diperlukan dalam proses laminasi per satuan luas (meter ${ }^{2}$ ) badan kapal PSP 01. Data mengenai hasil pengukuran alat dan bahan yang dibutuhkan proses laminasi per satuan luas $\left(\right.$ meter $\left.^{2}\right)$ badan kapal, tahapan proses laminasi, dan hasil wawancara tersebut selanjutnya dianalisis secara deskriptif, dan dilakukan perhitungan bahan yang dibutuhkan untuk melakukan laminasi per satuan luas (meter ${ }^{2}$ ) badan kapal, sedangkan untuk data daftar barang serta biaya disusun dalam tabel dan dihitung total keseluruhannya.

\section{Analisis deskriptif}

Analisis deskriptif pada penelitian ini digunakan untuk menjelaskan informasi mengenai tahapan laminasi KM PSP 01 di Palabuhanratu. Hasil olahan data dalam bentuk rangkuman hasil wawancara, perngukuran langsung, dan observasi mengenai tahapan laminasi kapal dipaparkan secara deskripsi. Analisis ini dilakukan dengan menyajikan informasi mengenai tahapan laminasi kapal, mulai dari material yang dibutuhkan, pra pengerjaan laminasi, proses laminasi, dan penyelesaian akhir dilengkapi dengan gambar dan foto. 


\section{Pembuatan formulasi kebutuhan bahan}

Pembuatan formulasi kebutuhan bahan laminasi dilakukan dengan cara menghitung alat dan bahan laminasi yang dibutuhkan persatuan luas (meter) badan kapal seperti pada Gambar 1, dan akan didapatkan formulasi mengenai kebutuhan laminasi kapal.

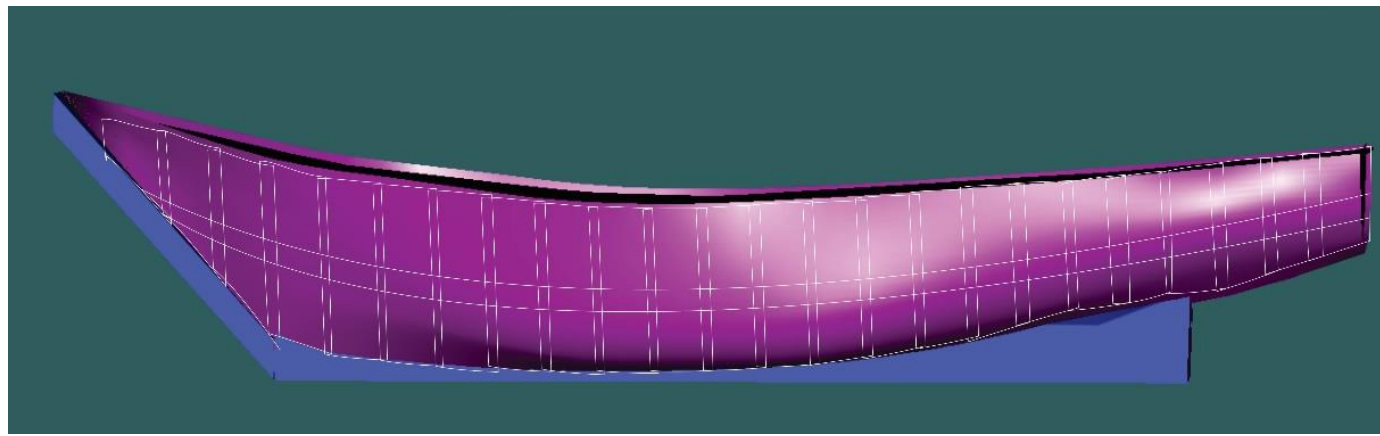

Gambar 1 pembagian luas kapal permeter

Perhitungan kebutuhan laminasi dilakukan dengan cara mencari nilai standar kebutuhan bahan laminasi terlebih dahulu. Untuk mendapatkan nilai standar kebutuhan laminasi, dilakukan dengan cara menghitung volume/ banyaknya bahan utama yang dipakai untuk melaminasi 1 meter badan kapal. Pada penelitian ini, juga dicari formulasi kebutuhan dempul kapal, dan formulasi kebutuhan laminasi kapal berdasarkan luasan badan kapal. Nilai standar kebutuhan laminasi dibagi atas beberapa jenis yakni :

1. nilai standar kebutuhan resin (Volume Resin dalam ml)

2. nilai standar kebutuhan mat (Luasan mat dalam meter)

3. nilai standar kebutuhan katalis (Volume katalis dalam $\mathrm{ml}$ )

Setelah semua data tersebut didapatkan, maka didapatkan nilai standar kebutuhan bahan untuk melaminasi badan kapal 1 lapis per 1 meter. Kemudian nilai tersebut dapat digunakan untuk menghitung kebutuhan laminasi pada kapal dengan formulasi yang didapatkan pada saat penelitian dilapangan. Untuk menghitung banyaknya bahan yang dipakai, dilakukan pengambilan data 10 sampel lembar fibreglass perlapis, dan kemudian dirata-ratakan agar mendapat nilai standar kebutuhan bahan.

\section{Perhitungan Biaya Laminasi}

Perhitungan biaya laminasi pada penelitian ini digunakan untuk mengetahui besaran Modal tetap (fixed investment) yakni dana yang dibutuhkan untuk membiayai pengadaan barang modal. Biaya yang dihitung dalam analisis ini yakni

1. Upah tenaga kerja

2. biaya total alat dan bahan

Semua biaya yang ada, ditabulasikan dan dihitung biaya totalnya sehingga dapat menjadi referensi biaya laminasi.

\section{HASIL DAN PEMBAHASAN}

Kapal PSP 01 merupakan kapal penangkap ikan yang memiliki desain kasko berupa roundbottom tipe mono hull. Kapal PSP 01 merupakan kapal penangkap ikan yang dibangun dalam rangka pengembangan kompetensi Departemen Pemanfaatan Sumberdaya Perikanan FPIK IPB yaitu teaching farm industry berbasis perikanan tangkap Kapal yang pembuatannya ditujukan bagi kepentingan riset (penelitian) dan usaha penangkapan ikan ini dibiayai oleh Program A3 dan resmi diluncurkan pada bulan Juni Tahun 2008 (Susanto, 2010). Spesifikasi teknis dari kapal PSP 01 disajikan pada Tabel 2. 
Tabel 1 Spesifikasi kapal PSP 01

\begin{tabular}{rlc}
\hline No & \multicolumn{2}{c}{ Keterangan } \\
\hline 1 & Nama & PSP 01 \\
2 & Tahun pembuatan & 2008 \\
3 & Bahan & Kayu \\
4 & LOA & 14,30 meter \\
5 & LPP & 12,41 meter \\
6 & Lebar (B) & 3,12 meter \\
7 & lebar pada garis air (BWL) & 3,03 meter \\
8 & dalam (D) & 1,20 meter \\
9 & Draft (d) & 0,96 meter \\
10 & Tonase & 9,5 GT \\
11 & Tenaga Penggerak & mitsubishi 4D30, 80 PS \\
\hline
\end{tabular}

Untuk mencari luas badan kapal PSP 01, digunakan software "maxsurf". Cara mendapatkannya adalah dengan memasukkan semua data panjang kapal, jarak ordinat, dan ukuran kelengkungan tiap ordinat kapal yang didapat dari lines plan. Setelah memasukkan semua data pada software, maka akan didapat hasil sebagaimana disajikan pada Gambar 2.

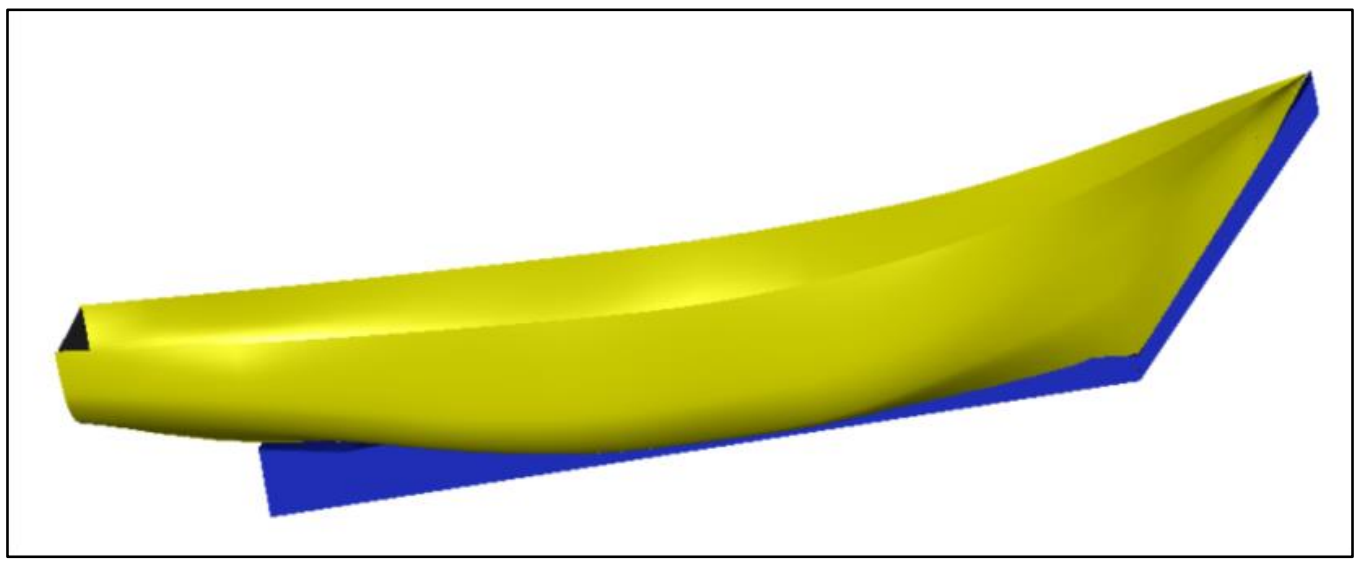

Gambar 2 Bentuk 3D kapal PSP 01

Jika semua data sudah diinput dan gambar sudah terbentuk, kita tinggal mengklik fitur data-calculate area. Dari fitur tersebut, akan keluar luas area kapal sebagaimana pada gambar berikut:

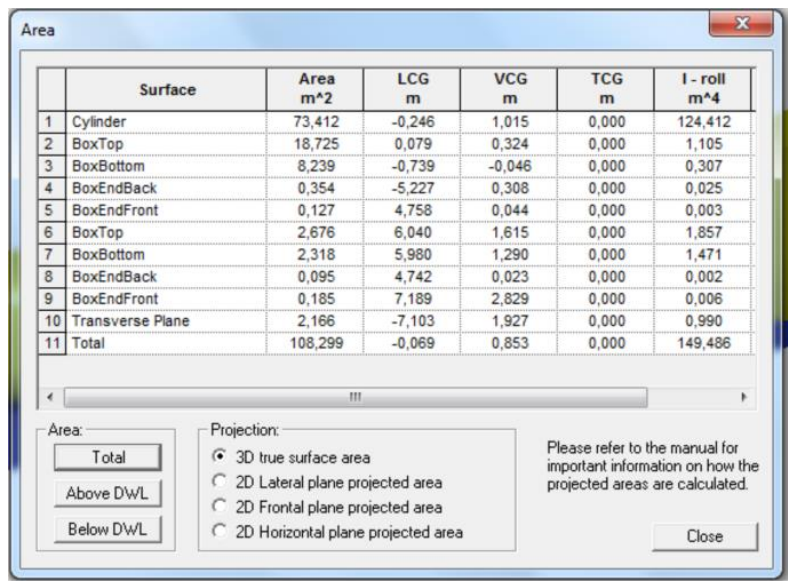

Gambar 3 Hasil perhitungan luas area pada maxsurf 
Dari hasil perhitungan, didapatkan hasil luas badan/kulit kapal PSP 01 sebesar 108,2 meter persegi.

\section{Material Laminasi Kapal}

Proses laminasi kapal membutuhkan beberapa alat dan bahan utama seperti diperlihatkan pada Tabel 3 berikut ini:

Tabel 2 Alat dan Bahan Laminasi

\begin{tabular}{ll}
\hline \multicolumn{1}{c}{ Alat dan bahan } & \multicolumn{1}{c}{ keterangan } \\
\hline Resin & Resin adalah media pengikat fiber dan sering dijumpai dalam \\
Mat dan roving (serat kaca) & Kentuk cair, kental, dan bening. \\
& Kaca serat (fiberglass) atau sering diterjemahkan menjadi serat \\
& kaca adalah kaca cair yang ditarik menjadi serat tipis dengan \\
& garis tengah sekitar 0,005 mm - 0,01 mm. Serat ini dapat dipintal \\
& menjadi benang atau ditenun menjadi kain, yang kemudian \\
& diresapi dengan resin sehingga menjadi bahan yang kuat dan \\
& tahan korosi untuk digunakan sebagai badan mobil dan \\
& bangunan kapal. \\
& Talc merupakan sejenis bubuk kapur yang berfungsi sebagai \\
& dempul setelah dicampur dengan resin dan katalis. \\
& Erosil merupakan Bubuk yang sangat halus,Bahan ini memiliki \\
Talc & fungsi sebagai perekat bahan mat sehingga fiberglass memiliki \\
& kekuatan dan tidak mudah patah atau pecah, dan berfungsi agar \\
Erosil & adonan resin menjadi lembut dan hasilnya lebih mengkilap. \\
& Katalis adalah sejenis bahan yang berfungsi sebagai penyebab \\
& reaksi kimia. Bahan ini berfungsi sebagai katalisator dan \\
& akselerator pada proses pengeringan. Fiberglass yang terlalu \\
& cepat dikeringkan, atau terlalu banyak campuran katalisnya \\
Katalis & akan lebih mudah pecah. Sifat dari katalis diantarany mudah \\
& meledak karena kandungan O2nya dinonaktifkan \\
& Baut berfungsi untuk memperkuat lapisan dasar laminasi serta \\
& sambungannya, sehingga tidak mudah lepas dari kayu \\
& Pigmen adalah campuran yang digunakaan untuk memberikan \\
Karna pada lapisan luar fiberglass yang dikehendaki & Mesin gerinda adalah mesin yang berfungsi untuk memotong \\
Kuas roll & atau menggerinda. Didalam laminasi, gerinda berfungsi untuk \\
Bayung & menghaluskan permukaan kapal dan memotong bagian kasko \\
kapal yang sudah kurang bagus. & Kuas roll ini berfungsi untuk melapis kapal menggunakan resin \\
dan fiberglass & Kape berfungsi untuk mendempul bagian kapal yang tidak rata \\
& Sebagai wadah untuk resin yang akan digunakan \\
Mesin gerinda tangan & \\
&
\end{tabular}

\section{Metode Laminasi Kapal}

Metode laminasi kapal terdiri atas 3 tahapan utama, tahap pertama yakni perbaikan dan pendempulan permukaan kapal, tahap kedua yakni pelapisan FRP yang terdiri atas pelapisan mat, pelapisan roving, dan pelapisan kembali dengan mat, serta tahap ketiga yakni pengecatan kapal sebagai penyelesaian akhir. teknik ini menghasilkan lapisan yang sama dengan konstruksi lapisan kapal FRP, namun tekniknya dilakukan secara terbalik. Jika pada beberapa literatur menyebutkan Teknik pembuatan kapal FRP dilakukan dengan melapisi gelcoat ke permukaan, kemudian dilapisi dengan mat dan roving secara berulang sampai didapatkan tebal yang diinginkan, pada laminasi kapal 
kayu dilakukan pelapisan mat dan roving terlebih dahulu sampai didapat tebal yang diinginkan dan diakhiri dengan pelapisan gelcoat (Wave Train, 2011).

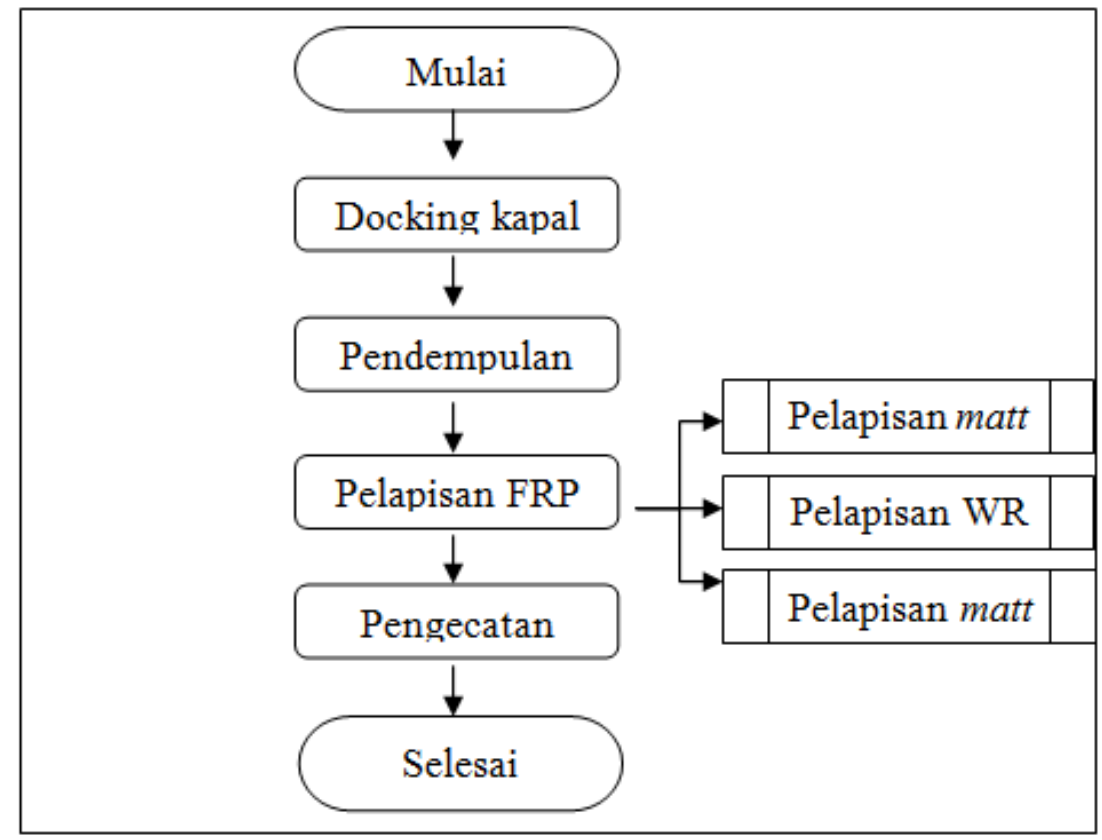

Gambar 4 Diagram alir pengerjaan laminasi kapal

\section{Tahap 1 : Perbaikan dan pendempulan permukaan kapal}

Proses perbaikan ini bertujuan untuk membuat permukaan badan kapal yang akan dilaminasi menjadi rata dan halus, serta menutupi lubang yang ada sehingga tidak menimbulkan gelembung udara saat dilaminasi (Michigan Fibreglass, 2010). Proses perbaikan dimulai dengan menambal bagian kayu lambung kapal yang hilang menggunakan kayu baru, dan mengganti bagian kayu lambung kapal yang sudah sangat lapuk. Setelah itu, dilakukan proses pendempulan bagian kapal yang berlubang atau memiliki celah menggunakan dempul resin. Menurut literatur yang ada, dempul yang digunakan untuk melakukan perbaikan permukaan kapal adalah jenis gelcoat atau adonan resin yang dicampur dengan erosil. Namun dempul untuk kapal PSP 01 sendiri dibuat dari campuran resin dan talc, dengan perbandingan yang umum ditetapkan oleh pengrajin fiberglass sebagai berikut (Performance Yacht System, 2010):

Formula

$1 \mathrm{~kg}$ resin : $2 \mathrm{~kg}$ semen talc : $2 \%$ katalis

Tujuan penggunaan dempul resin dan talc sebagai bahan untuk mendempul adalah :

a. Lebih murah dan efisien dibandingkan dempul mobil

b. Hasil dempul lebih ringan.

c. Lebih menempel erat dengan FRP laminasi karena merupakan bahan sejenis. 


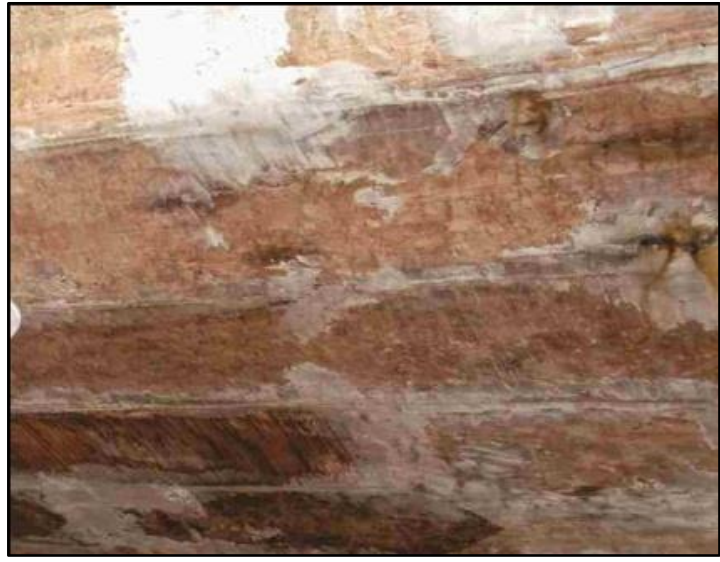

Gambar 5 Kapal sudah didempul

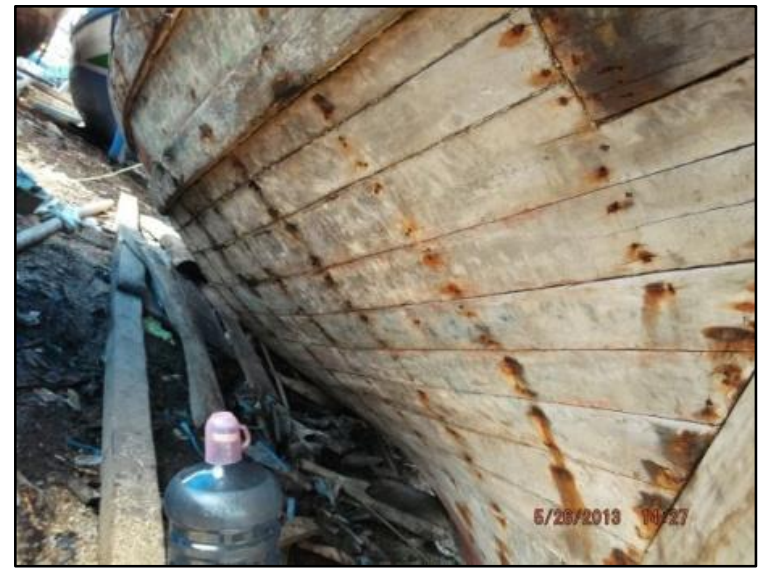

Gambar 6 Kapal Sebelum didempul

\section{Tahap 2 : Pelapisan FRP}

Proses pelapisan menggunakan dua jenis bahan serat kaca yang berupa mat dan roving. Mat dan roving memiliki beberapa jenis susunan, bentuk, dan berat serat yang berbeda, namun yang paling membedakan antara mat dan roving adalah susunan seratnya. Mat memiliki susunan serat acak seperti jerami dan dibentuk seperti lembaran. Menurut FAO, didalam pembuatan kapal fiberglass digunakan jenis mat dan roving yang beragam untuk menyesuaikan kebutuhan dari kapal, seperti penggunaan mat 300 untuk lapisan permukaan agar halus, dan menggunakan mat 450 untuk memperkuat lapisan. Roving yang digunakan adalah perpaduan roving 600 dan 800 agar terbentuk lapisan yang kokoh namun tetap halus.

Untuk Jenis Mat yang digunakan untuk laminasi PSP 01 adalah mat 450. Penggunaan mat jenis ini sesuai dengan Literatur lainnya yang menyebutkan bahwa mat yang cocok untuk laminasi kayu adalah jenis mat 450. Mat yang disiapkan Pada laminasi kapal PSP01 sebanyak 1 roll dengan spesifikasi lebar 1 meter dan panjangsekitar 75 meter.

Roving merupakan serat kaca yang memiliki susunan serat seperti karung. Roving merupakan serat kaca yang mudah dibentuk karena susunannya yang fleksibel. Pada pengerjaan laminasi kapal PSP01, Jenis roving yang digunakan adalah roving 600.

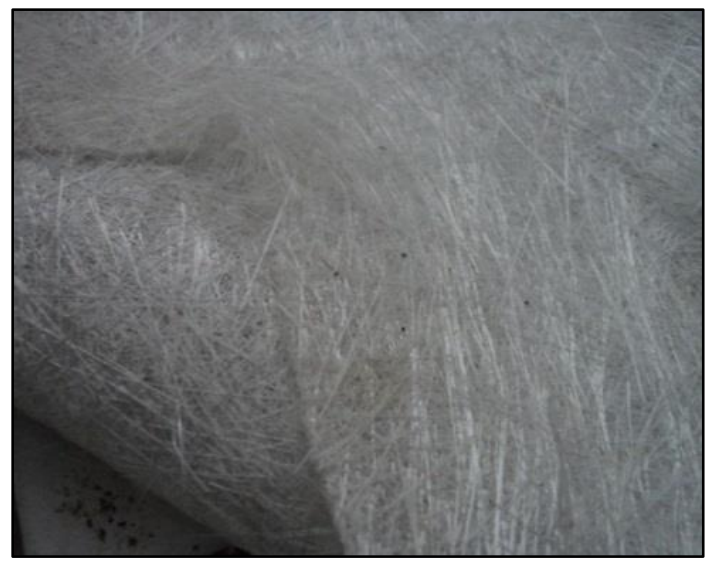

Gambar 7 mat

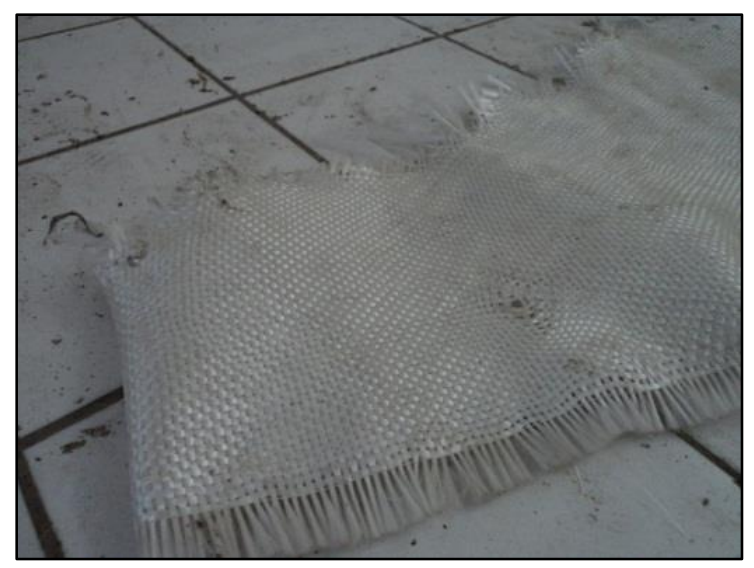

Gambar 8 Roving

Roving yang disiapkan untuk laminasi kapal ini sebanyak 1 roll, dengan spesifikasi lebar 1 meter dan panjang 75 meter. Untuk laminasi kapal, mat dan roving dipotong dengan ukuran 1 meter x 1,2 meter seperti pada Gambar 7. Hal ini bermaksud agar tiap serat kaca memiliki sambungan 20 cm dengan serat kaca lainya. 


\section{$1,2 \mathrm{~m}$}

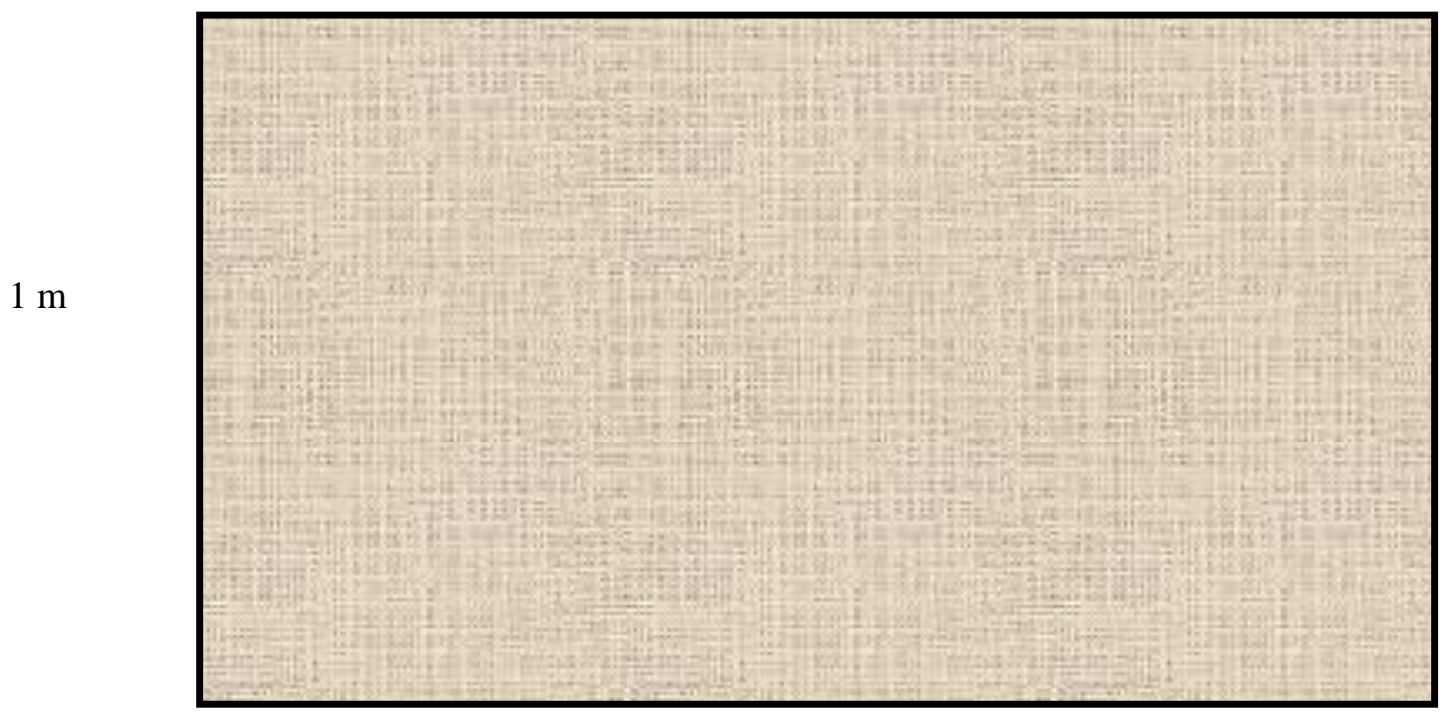

Gambar 9 ukuran potongan fibreglass

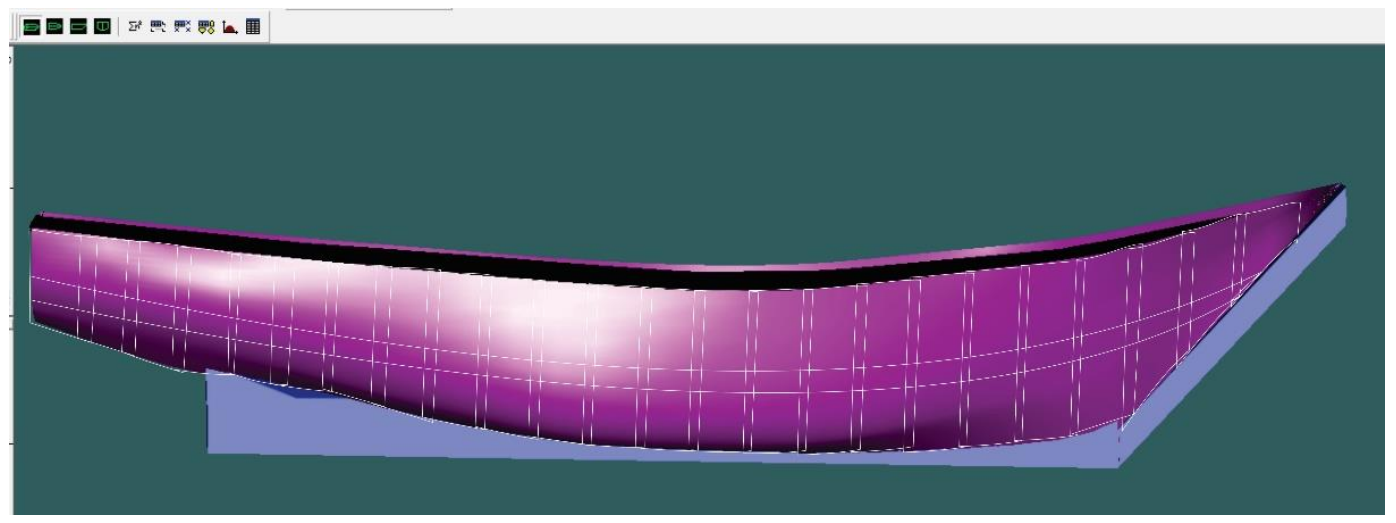

Gambar 10 Skema kerja laminasi

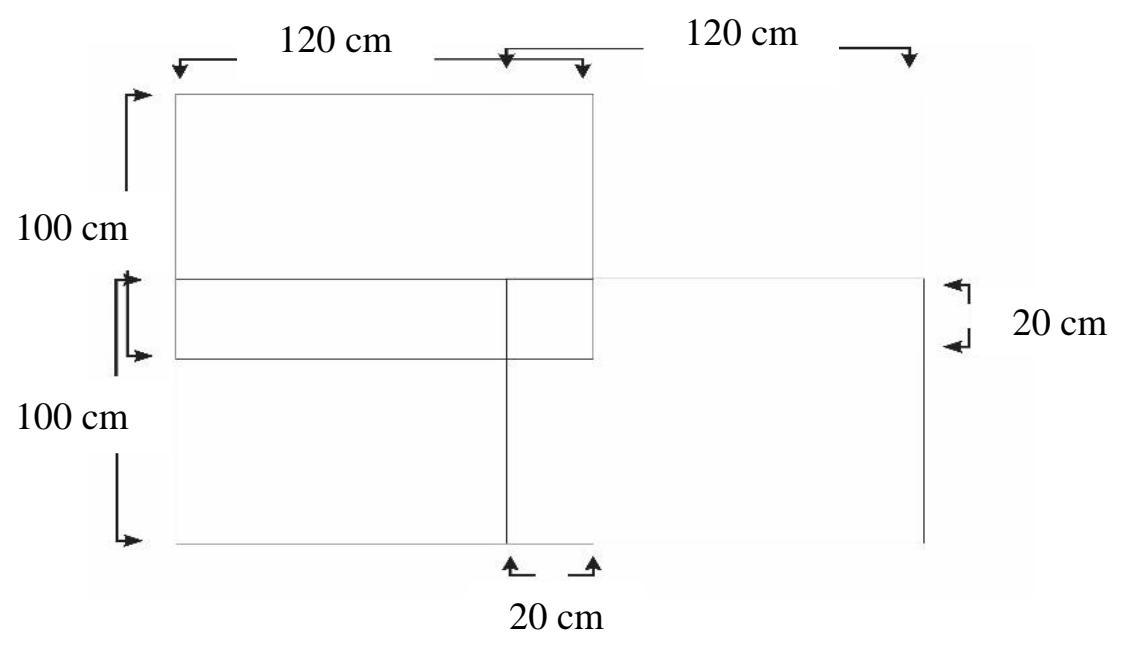

Gambar 11 Bentuk dan ukuran potongan fibreglass yang ditempel 
Menurut FAO, jumlah lapisan untuk kapal fiberglass dibedakan untuk tiap bagian kapal. Jumlah lapisan yang paling tebal yakni 12 lapis untuk bagian bottom, dengan menggunakan mat dan roving secara bergantian, dan gelcout sebagai lapisan terluar. Kapal PSP-01 dilaminasi dengan 3 lapisan. Lapisan pertama menggunakan mat sebagai dasar FRP, lapisan kedua menggunakan roving. Lapisan ketiga kapal menggunakan mat agar permukaan lebih halus, dan dicat dengan resin sehingga lebih rapi. Tebal ketiga lapisan laminasi tersebut adalah sekitar 4-5 mm.

\section{Pelapisan dengan mat I}

Kapal dilapisi dengan mat yang sudah dipotong dengan ukuran 1 meter x 1,2 meter. Teknik melapisnya yakni dari bagian bawah lambung kapal, tepatnya dari setengah lunas terlebih dahulu, menuju bagian atas. Pertama, bagian yang ingin dilaminasi dilapisi resin yang sudah dicampur katalis terlebih dahulu sampai basah, kemudian mat ditempel kebagian tersebut. Tujuan dari teknik pelapisan tersebut yakni agar mat menempel sehingga memudahkan pekerjaan, dan agar tidak menimbulkan gelembung udara saat dilapis. Menurut literatur yang ada, permukaan kayu yang bergelombang, berlubang, dan tidak rata dapat menyebabkan hasil laminasi berongga karena terjadi oksidasi dan reaksi pelepasan udara didalam lapisan fiberglass (Vendik 2010). Setelah menempel, mat kemudian dilapisi kembali dengan resin hingga terlihat transparan dan menyatu dengan kayu lambung kapal.

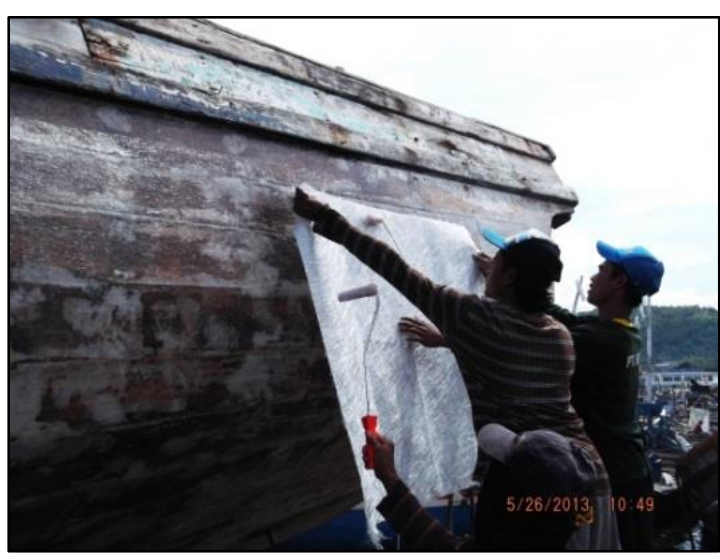

Gambar 12 pelapisan dengan mat

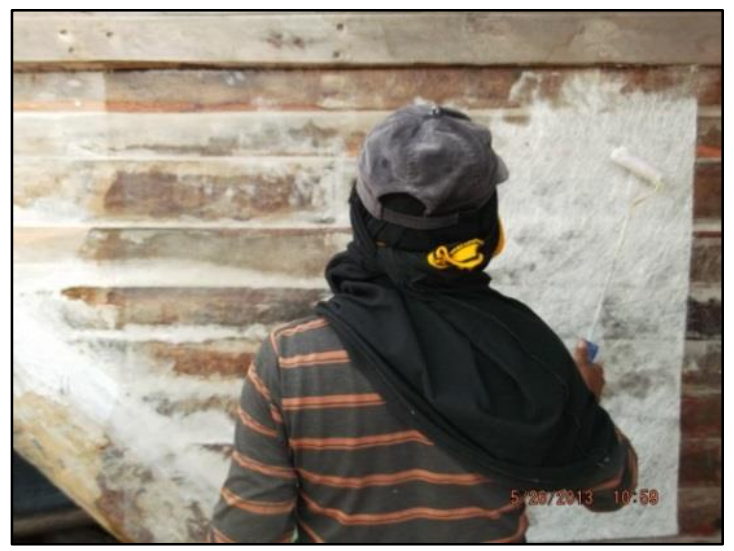

Gambar 13 Pelapisan dengan mat

\section{Pelapisan dengan roving}

Kapal dilapisi dengan roving yang sudah dipotong dengan ukuran 1 meter $\mathrm{x}$ 1,2 meter. Pelapisan roving dilakukan ketika lapisan mat pertama sudah mengeras dan kering sempurna. Menurut Sari (2010), Pelapisan dengan menggunakan roving bertujuan untuk menambah nilai modulus elastisitas (MOE) dan modulus patahnya (MOR), sehingga menghasilkan perpaduan serat yang lentur dan kuat. Teknik pelapisan roving sama dengan saat pelapisan pertama, yakni dengan melapisi bagian yang akan dilaminasi dengan resin, kemudian ditempel dengan roving. Roving yang sudah menempel kemudian dilapisi dengan resin sampai menyatu dengan lapisan pertama. 


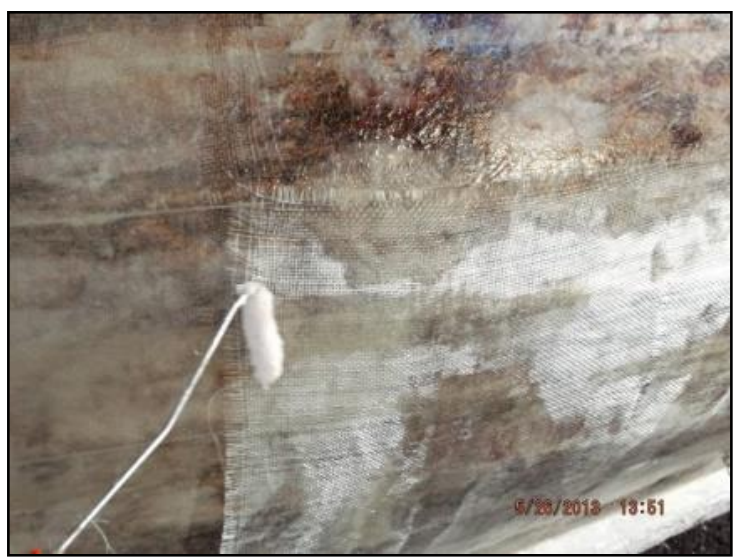

Gambar 14 Pelapisan dengan roving

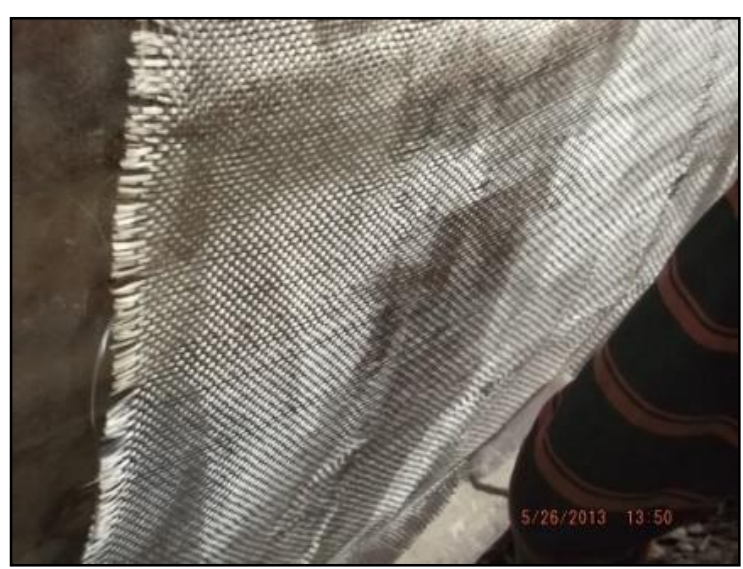

Gambar 15 Pelapisan dengan roving

\section{Pelapisan dengan mat II}

Kapal yang sudah dilapisi roving kemudian ditutup dengan mat selagi kondisi roving masih belum mengering. Hal ini bertujuan agar lapisan FRP menjadi rapi, dan pori-pori yang ada pada roving tertutupi. Teknik melapis yang digunakan sama dengan lapisan sebelumnya. Lama waktu kering untuk sebuah lapisan FRP dipengaruhi oleh banyaknya katalis, suhu, serta cuaca. FAO memberikan standar waktu untuk pengeringan sempurna fibreglass yakni 24 jam pada suhu 40 derajat celcius. Menurut literatur yang ada, didalam selang waktu beberapa jam, terkadang ada bagian dari hasil fiberglass yang belum kering sempurna, sehingga mesti ditunggu hingga 24 jam agar semua bagian sudah kering secara merata.

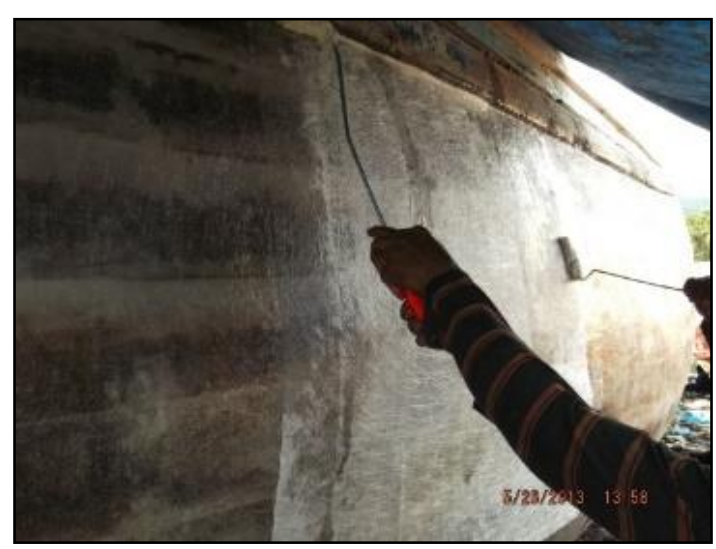

Gambar 16 Pelapisan dengan mat

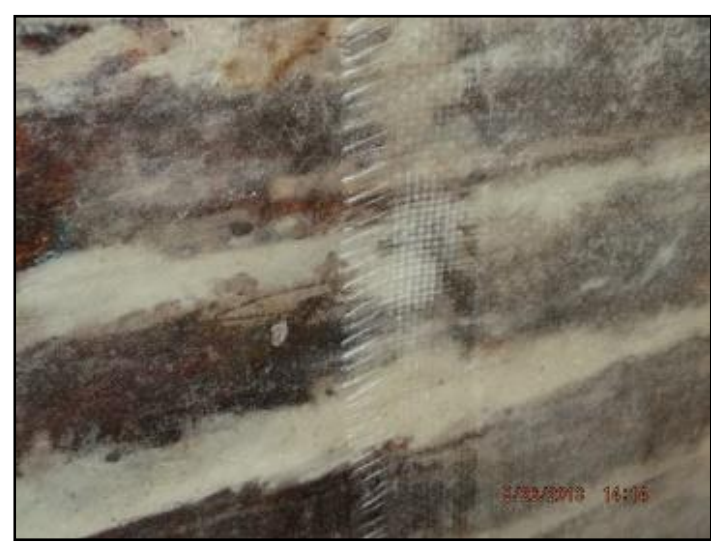

Gambar 17 pelapisan dengan mat

\section{Tahap 3 : Pengecatan}

Proses terakhir dari laminasi kapal adalah pengecatan sebagai lapisan terluar. Pengecatan dilakukan dengan menggunakan gelcoat yang dibuat agak encer. Hal ini mengacu pada kapal FRP yang memiliki lapisan mat, roving, mat dan gelcoat pada bagian terluarnya (Ma'ruf B. 2010). Pengecatan badan kapal berfungsi untuk memperindah kapal, membuat daya tahan kapal dari pembusukan, menutup pori-pori kapal yang dapat menyebabkan kebocoran, serta mencegah fiber pada kapal terkelupas atau rusak dengan cepat. proses pengecatan kapal menggunakan bahan-bahan seperti pigment resin, resin, katalis, dan erosil. Penggunaan cat yang berbahan dasar resin, kobalt, erosil, dan pigment warna berfungsi agar daya rekat cat lebih kuat, dan dapat menambah kekuatan serta daya tahan hasil laminasi. Hasil pengecatan menggunakan bahan tersebut juga tidak akan mudah terkelupas seperti kapal kayu lainnya, sehingga mengurangi biaya perawatan pengecatan kapal. 


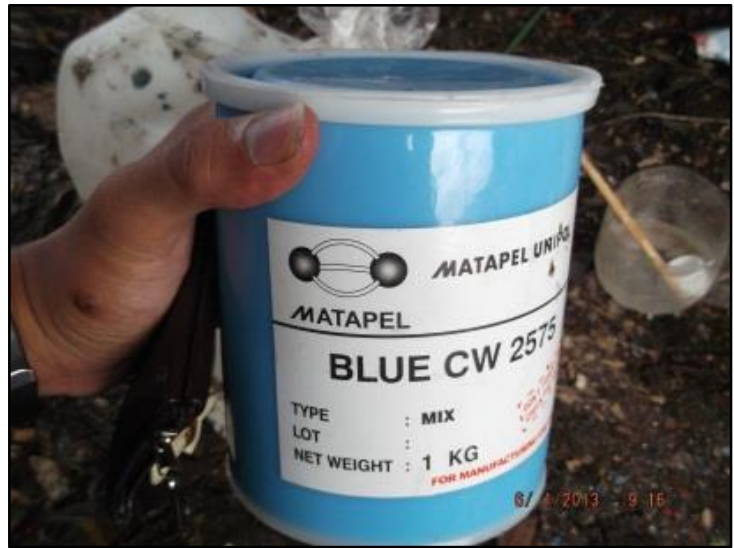

Gambar 18 Pigmen warna

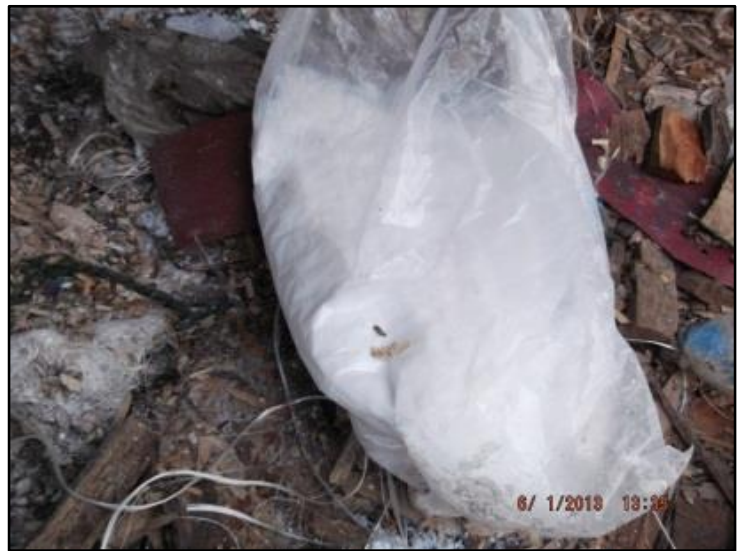

Gambar 19 Erosil

Pembuatan cat resin ini dilakukan dengan cara mencampurkan resin dengan pigmen warna, lalu ditambah dengan erosil secukupnya. Pada pengecatan kapal PSP-01, digunakan pigmen warna putih dan biru seperti pada Gambar 21.

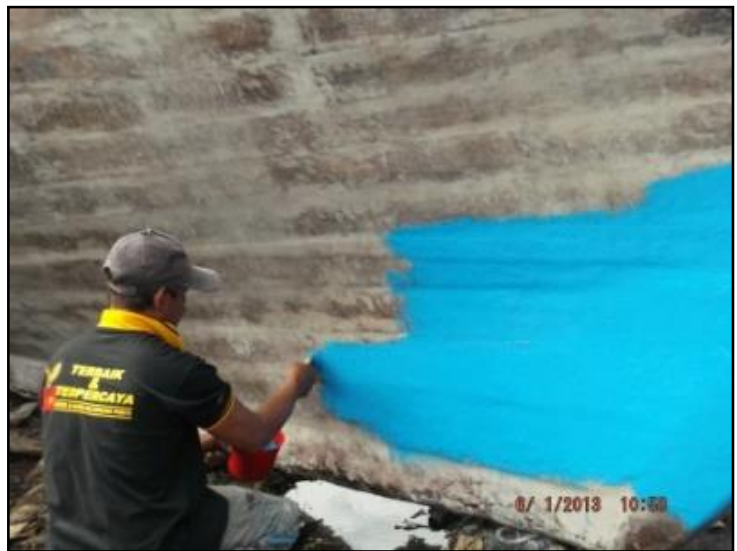

Gambar 20 pengecatan kapal

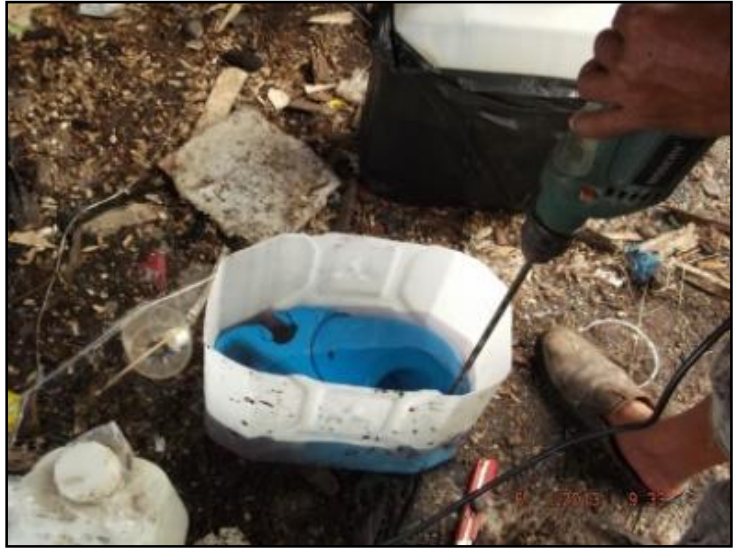

Gambar 21 Pencampuran bahan cat

Dari hasil pengerjaan laminasi kapal tersebut, didapatkan perbandingan antara pengerjaan laminasi di lapangan dengan teknik laminasi yang sesuai standar. Perbandingan tersebut disajikan pada Tabel 4.

Tabel 4 Perbandingan Kesesuaian Kerja Laminasi (McVeagh et al, 2010)

\begin{tabular}{|c|c|c|c|}
\hline & standar pengerjaan & temuan dilapangan & sesuai/tidak \\
\hline \multirow[t]{3}{*}{ Pendempulan } & $\begin{array}{l}\text { bahan dempul menggunakan } \\
\text { gelcoat } \\
\text { semua celah dan pori-pori }\end{array}$ & $\begin{array}{l}\text { bahan dempul menggunakan } \\
\text { talc dan resin } \\
\text { semua celah dan pori-pori }\end{array}$ & tidak \\
\hline & ditutup & ditutup. & ya \\
\hline & $\begin{array}{l}\text { mat menggunakan } \\
\text { perpaduan CSM 350, CSM }\end{array}$ & & \\
\hline \multirow{4}{*}{ Pelapisan FRP } & 450 & mat menggunakan CSM 450 & tidak \\
\hline & $\begin{array}{l}\text { roving menggunakan } \\
\text { perpaduan WR } 450, \text { WR }\end{array}$ & & \\
\hline & 600, WR 800 & roving menggunakan WR 600 & tidak \\
\hline & $\begin{array}{l}\text { urutan hasil lapisan : gelcoat, } \\
\text { mat, roving, mat. } \\
\text { teknik lapis : resin, fiber, } \\
\text { resin }\end{array}$ & $\begin{array}{l}\text { urutan hasil lapisan : gelcoat, } \\
\text { mat, roving, mat }\end{array}$ & ya \\
\hline
\end{tabular}




\begin{tabular}{llll}
\hline & standar pengerjaan & temuan dilapangan & sesuai/tidak \\
\hline & penggunaan jenis resin : & & \\
& yucalac/polyester resin & penggunaan jenis resin : eterna & tidak \\
& penggunaan katalis $=2 \%$ & penggunaan katalis $=4-5 \%$ & tidak \\
& menggunakan gelcoat yang & $\begin{array}{l}\text { menggunakan gelcoat yang } \\
\text { diberi pigmen warna }\end{array}$ & ya \\
Pengecatan & diberi pigmen warna & & \\
& tertutup, berventilasi dan & & tidak \\
Tempat kerja & exhaust system, memiliki & terbuka, becek, tidak memiliki & \\
& ruangan penyimpanan & tempat penyimpanan & \\
Keselamatan & sarung tangan, kacamata, & & \\
kerja & masker, wearpak, sepatu & tidak menggunakan alat & tidak \\
\hline
\end{tabular}

\section{Formulasi Kebutuhan Bahan Laminasi}

Untuk mencari jumlah kebutuhan bahan, kita harus mencari banyaknya lembaran fiberglass yang dibutuhkan. Jumlah lembaran fiberglass yang digunakan dapat kita cari dengan membagi luasan kapal yang ada dengan standar luasan fiberglass, ditambah dengan total luas lembar overlay. Luas badan kapal dapat kita cari dengan memasukkan data lines plan kedalam software "maxsurf", sehingga kita bisa mendapatkan luas areanya. Standar ukuran fiberglass yang digunakan untuk laminasi kapal adalah 1 meter x 1,2 meter atau menyesuaikan luasan fiberglass yang digunakan untuk laminasi. Dari data tersebut, maka dapat diformulasikan rumus untuk mencari jumlah kebutuhan lembaran fiberglass sebagai berikut berikut :

$$
\mathrm{TLn}=\mathrm{LBK} / 1,2 \mathrm{~m}
$$

Ket : TLn : total lembarfiberglass (tanpa overlay)

$1,2 \mathrm{~m} \quad$ : luas standar fiberglass laminasi.

LBK : luasan total badan kapal yang akan dilaminasi (dihitung menggunakan software maxsurf).

Rumus diatas digunakan untuk menghitung jumlah kebutuhan fiberglass, namun belum secara keseluruhan (belum ditambah luas fiberglass overlay). Luas dari fiberglass overlay perlembar adalah 0,44 meter. pada fiberglass pertama disetiap lapisan, serat overlay tidak dihitung karena tidak ada overlay yang dipakai. Dari data tersebut, maka dapat diformulasikan rumus total lembar overlay sebagai berikut :

$$
\begin{aligned}
& \text { TLoverlay }=\frac{(\mathrm{TLn}-1) \times 0,44 \mathrm{~m}}{1,2 \mathrm{~m}} \\
& \text { Ket : TLoverlay : total lembarfiberglass overlay } \\
& \text { TLn : total lembar fiberglass (tanpa overlay) }
\end{aligned}
$$

Dari rumus diatas, maka dapat kita hitung kebutuhan total lembar fiberglass dengan menjumlahkan TLn dan TLoverlay.

Ket : $\quad$ TLfix

$$
\text { TLfix }=\text { TLn }+ \text { TLoverlay }
$$

TLn : total lembar fiberglass(tanpa overlay)

TLoverlay : total lembar overlay 


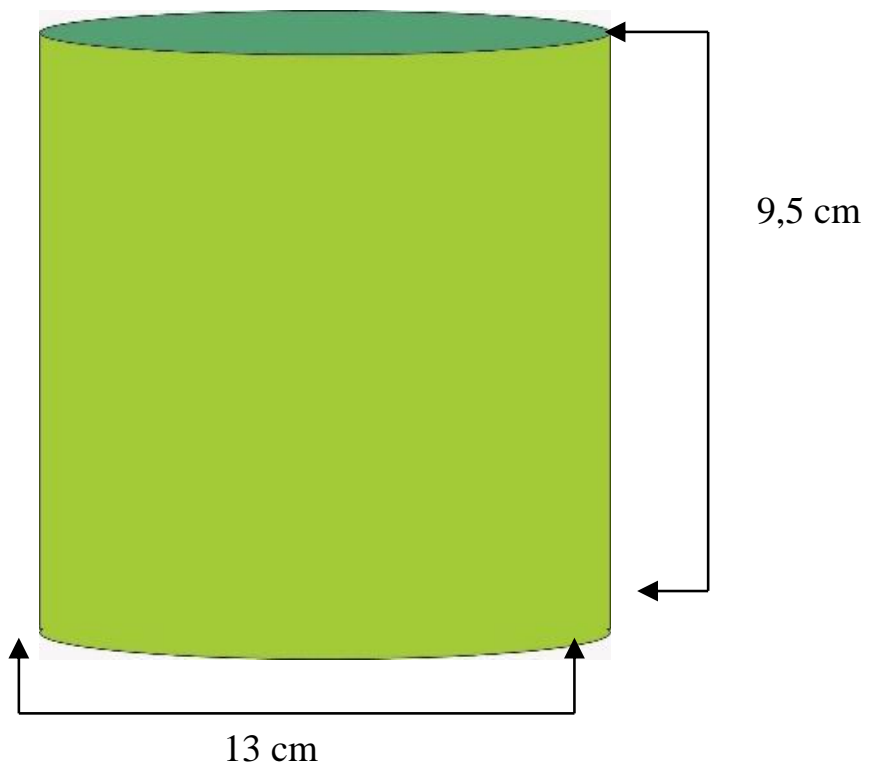

Gambar 22 Ukuran wadah resin untuk laminasi

Pengukuran dilakukan terhadap jumlah resin dalam wadah yang terpakai perlembar fiberglass, dan Pada proses laminasi ini, gayung digunakan sebagai wadah resin. Berikut pada Tabel 3 diperlihatkan hasil pengukuran dari penggunaan resin ditiap lapisan (Fibreglassite, 2010).

Tabel 5 Volume pemakaian resin perlembar fibreglass

\begin{tabular}{lcr}
\hline Resin lapisan 1 (cm3) & Resin lapisan 2 (cm3) & Resin lapisan 3 (cm3) \\
\hline 1260,31 & 1008,25 & 1260,31 \\
945,23 & 1260,31 & 1134,28 \\
1008,25 & 945,23 & 1008,25 \\
945,23 & 1008,25 & 1260,31 \\
1008,25 & 1260,31 & 1260,31 \\
1260,31 & 1008,25 & 1008,25 \\
1008,25 & 1260,31 & 882,22 \\
1008,25 & 1134,28 & 1008,25 \\
1134,28 & 1260,31 & 1134,28 \\
\hline 1064,26 & 1127,28 & 1106,27 \\
\hline
\end{tabular}

Dari lapisan pertama, didapatkan rata-rata resin yang habis sebesar 1064,26 $\mathrm{cm}^{3}$.Rata-rata resin habis pada lapisan kedua sebesar 1127,28 $\mathrm{cm}^{3}$, dan rata-rata resin habis pada lapisan ketiga adalah sebesar 1106,27 $\mathrm{cm}^{3}$. Dari hasil tersebut, kemudian kita rata-ratakan ketiganya, sehingga didapatkan hasil nilai standar kebutuhan resin (NSKB resin) sebesar 1099,27 $\mathrm{cm}^{3}$. Dengan didapatnya hasil tersebut, dapat kita formulasikan rumus kebutuhan resin sebagai berikut:

\section{TBresin $=$ NSKB resin $\mathrm{X}$ TLfix}

Ket : $\quad$ TB resin : total kebutuhan resin

NSKB : nilai standar kebutuhan bahan resin

Tlfix : total semua lembar fiberglass yang dibutuhkan 
Katalis merupakan senyawa yang berfungsi sebagai katalisator dan akselerator pada proses pengeringan. Fiberglass yang terlalu cepat dikeringkan, atau terlalu banyak campuran katalisnya akan lebih mudah pecah. Standar maksimal penggunaan katalis yang ditetapkan produsen resin dan standar FAO adalah 2\%, agar hasil fiberglass menjadi bagus dan kokoh. Untuk menghitung nilai kebutuhan katalis,dapat kita gunakan rumus sebagai berikut :

$$
\text { TBkatalis }=2 \% \times \text { TBresin }
$$

Ket : TB katalis : total kebutuhan katalis

TB resin : total kebutuhan resin

\section{Perhitungan Biaya Laminasi}

Bahan yang digunakan selama proses laminasi disajikan pada Tabel 4 berikut :

Tabel 6 Biaya laminasi

\begin{tabular}{llrr}
\hline Bahan & Jumlah & Harga/pcs (Rp) & Total (Rp) \\
\hline chopped s mat450 & 1 roll & 720.000 & 720.000 \\
Roving 600 & 1 roll & 660.000 & 660.000 \\
resin merah & 10 jerigen & 290.000 & 2.900 .000 \\
Katalis & $2 \mathrm{~kg}$ & 54.000 & 108.000 \\
talcum powder & $2 \mathrm{karung}$ & 60.000 & 120.000 \\
Erosil & $10 \mathrm{~kg}$ & 92.000 & 920.000 \\
kuas 2,5 inch & $10 \mathrm{pcs}$ & 7.000 & 70.000 \\
kuas roll & $5 \mathrm{pcs}$ & 15.000 & 75.000 \\
Roll & $30 \mathrm{pcs}$ & 2.000 & 60.000 \\
Gayung & $5 \mathrm{pcs}$ & 4.000 & 20.000 \\
Mur & $1 \mathrm{ons}$ & 10.000 & 10.000 \\
pigmen warna blue cw & $1 \mathrm{~kg}$ & 105.000 & 105.000 \\
pigmen warna white & $1 \mathrm{~kg}$ & 83.000 & 83.000 \\
Upah tenaga kerja & & & 6.000 .000 \\
\hline Total & & & 11.851 .000 \\
\hline
\end{tabular}

Perhitungan biaya laminasi ini berguna untuk menghitung perkiraan biaya yang dibutuhkan untuk satu kali laminasi. Untuk menghitung besaran biaya yang dibutuhkan per bahan, dapat menggunakan rumus:

\section{TCi : TB $i$ x harga barang $i$}

Ket : $\quad$ TCi : total cost bahan $i$ TB $i$ : total kebutuhan bahan $i$

Proses laminasi kapal PSP 01 terdiri atas tiga tahapan utama yang terdiri atas perbaikan dan pendempulan permukaan kapal, pelapisan FRP, dan pengecatan kapal sebagai penyelesaian akhir. proses perbaikan dan pendempulan satu sisi kapal PSP 01 membutuhkan waktu tiga hari. Proses ini berlangsung cukup lama karena banyaknya bagian kasko kapal yang rusak dan berlubang, sehingga dilakukan banyak perbaikan. Banyaknya bahan yang dibutuhkan untuk Pendempulan tergantung pada tingkat kerusakan dan besarnya celah antar kayu kasko. Dempul yang digunakan seharusnya adalah jenis gelcoat agar hasilnya menjadi sangat kuat, namun hasil temuan lapang menunjukkan bahwa perbaikan dan pendempulan yang dilakukan untuk kapal PSP 01 menggunakan campuran resin dan talc. 
Pelapisan FRP dilakukan sebanyak tiga lapisan yang berupa pelapisan mat, roving, dan mat. pelapisan mat yang pertama bertujuan untuk menutup semua kayu kasko kapal sehingga pori-pori dan lubang yang terdapat pada kayu tertutup dengan baik. Pada proses pelapisan pertama ini juga dilakukan penanaman baut setelah lapisan pertama kering. Hal ini bertujuan agar lapisan pertama menjadi lebih menempel erat dengan kasko dan mencegah lepasnya lapisan FRP dari kasko kapal. Pelapisan kedua dilakukan dengan menggunakan roving 600, yang berfungsi memperkuat lapisan FRP. Pelapisan ketiga dilakukan dengan menggunakan mat, yang berfungsi menutup semua pori-pori yang ada pada roving, sehingga lebih membuat kapal menjadi kedap air. mat 450 dan roving 600 digunakan pada laminasi karena perpaduan antara mat dan rovin jenis ini memiliki nilai MOE dan MOR yang tinggi (Sari. 2010), sehingga sangat kuat dan bagus untuk laminasi kapal. Jenis mat 450 dan roving 600 yang digunakan sudah sesuai dengan standar dari FAO dan literatur lainnya, karena menghasilkan perpaduan yang pas dari segi kedap air, elastisitas dan kekuatannya.

Pelapisan FRPdilakukan setelah semua bagian kapal telah rata dan halus. Hal ini bertujuan agar tidak ada gelembung udara akibat proses oksidasi resin yang timbul pada hasil FRP. Pada pekerjaan laminasi dilapangan, ketika ditemukan bagian dari laminasi yang bergelembung, maka bagian tersebut akan langsung dipotong dan dilaminasi ulang. Dari hasil pengamatan lapang, bagian FRP yang bergelembung tersebut cenderung tidak menempel pada dinding atau kasko kapal, sehingga dapat menyebabkan resiko retak dan lepas yang tinggi.

Lapisan Mat dan roving digunakan didalam laminasi kapal. Kedua bahan ini memiliki kontur serat dan ketebalan yang berbeda. Roving memiliki ketebalan yang lebih besar dibandingkan dengan mat, dan seratnya tersusun seperti karung sehingga banyak yang mengasumsikan bahwa roving membutuhkan lebih banyak resin. Namun pada penelitian lapang, didapatkan data penggunaan bahan resin untuk lapisan pertama, kedua, dan ketiga yang memiliki selisih yang sedikit. Dari hasil pengujian penulis, didapatkan fakta bahwa mat memiliki sifat menyerap resin, sehingga membutuhkan resin yang cukup banyak, sedangkan untuk roving yang memiliki ketebalan yang lebih besar membutuhkan jumlah resin yang hampir sama dengan mat. hal ini terjadi karena susunan serat kaca roving yang disusun rapat seperti karung, namun memiliki pori-pori atau celah diantara susunan serat, sehingga roving tidak bersifat menyerap resin seperti mat.

Didalam proses laminasi, bahan Resin membutuhkan katalisator untuk membuat resin mengeras, dan besaran standar katalis untuk resin yang diterapkan oleh pabrik resin, FAO, dan beberapa literatur adalah 2\%. pada proses laminasi PSP 01, pekerja menggunakan jumlah katalis hampir 4-5\%. Penggunaan katalis dengan jumlah tersebut disebabkan karena kondisi alam dilokasi laminasi yang tidak stabil, sehingga para pekerja ingin mempercepat proses pengeringan FRP agar tidak diguyur hujan saat kondisinya masih belum kering. Pemakaian katalis yang berlebihan dapat membuat reaksi panas pada resin, sehingga dapat mengurangi kualitas serta kekuatan resin.

Proses laminasi kapal membuat semua bagian kasko kapal tertutup, sehingga membuat kondisi kasko menjadi kedap air. Namun karena kondisi kasko yang sudah sangat kedap air, membuat air yang masuk dari bagian atas kapal kedalam palka terjebak didalamnya. Kayu kasko atau palka yang mengandung air juga tidak dapat menguapkan airnya, sehingga dapat mempercepat pembusukan kayu. Untuk mengatasi ini, seharusnya laminasi dilakukan di luar dan dalam kapal, sehingga mencegah pembusukan kayu kapal yang terjadi.

Didalam Laminasi kapal PSP01, didapatkan data jumlah kebutuhan bahan untuk satu kali laminasi. Dari data tersebut, penulis lalu membuat formulasi kebutuhan bahan utama laminasi berupa serat kaca, resin, dan katalis. Untuk Pembuatan formulasi ini membutuhkan data standar kebutuhan serat, nilai standar kebutuhan resin per lembar serat, dan nilai kebutuhan katalis yang diambil dari sampel laminasi kapal PSP01.Dari hasil penelitian, didapatkan luas standar serat mat dan rovin adalah 1,2 meter. Setelah diambil 10 sampel lembar serat dari lapisan mat, rovin, dan mat, didapatkan nilai standar kebutuhan bahan (NSKB) resin sebesar 1099,27 $\mathrm{cm}^{3}$ perlembar serat. Selain itu, penggunaan 
software maxsurf untuk menghitung luasan badan kapal digunakan didalam pembuatan formulasi ini, sehingga didapatkan rumus kebutuhan lembar serat mat dan rovin. Untuk mencari kebutuhan bahan utama laminasi (resin, serat, dan katalis), dapat dilakukan dengan cara menghitung luas badan kapal yang akan dilaminasi, lalu memasukkan data luas kapal tersebut kedalam formula yang sudah dibuat sehingga kita akan mendapatkan jumlah kebutuhan lembar serat non-overlay dan luas serat overlay.

Pengerjaan laminasi kapal PSP 01 sempat mengalami kehabisan bahan, sehingga membuat proses laminasi kapal menjadi tertunda. Kehabisan bahan laminasi disebabkan oleh kurangnya pengetahuan mengenai kebutuhan bahan. Kejadian seperti ini dapat dihindari dengan menghitung kebutuhan bahan laminasi menggunakan formula yang sudah dibuat, sehingga efisiensi waktu, biaya, dan tenaga dapat ditingkatkan.

Pelapisan yang dilakukan oleh pekerja orang yang sudah berpengalaman didalam laminasi kapal, maupun pembuatan kapal FRP, namun para pekerja ini masih belum dapat memperkirakan banyaknya bahan yang dibutuhkan untuk laminasi kapal. Hal ini membuat proses laminasi beberapa kali tertunda karena material yang habis. Selain itu kondisi alam yang tidak stabil dan hujan yang turun sangat lama membuat pengerjaan laminasi tertunda sampai beberapa hari. Para pekerja ini juga tidak menggunakan peralatan keselamatan seperti sarung tangan, masker, kacamata kerja, dan sepatu boot. Padahal, material seperti resin, katalis, talc dapat menyebabkan iritasi jika terkena kulit dan dapat menyebabkan kanker jika terhirup oleh paru-paru. Selain itu peralatan listrik yang ditaruh digalangan yang becek dapat mengakibatkan resiko para pekerja tersetrum. Hal ini sangat tidak sesuai dengan prosedur keselamatan standar yang sangat memperhatikan akibat dari pengerjaan dan bahan laminasi kapal (Latief, 2013).

\section{KESIMPULAN}

Laminasi kapal terdiri atas tiga tahapan utama yang berupa perbaikan dan pendempulan permukaan kapal, pelapisan FRP, dan pengecatan kapal. Tempat laminasi kapal dilakukan digalangan PPN Palabuhan ratu. Kondisi galangan yang terbuka membuat proses laminasi kapal menjadi terhambat oleh cuaca yang tidak stabil sehingga waktu laminasi kapal yang ditargetkan hanya 10 hari kerja menjadi hingga 20 hari kerja. Luas standar lembar serat yang dibutuhkan untuk laminasi adalah 1,2 meter. Nilai standar kebutuhan bahan (NSKB) resin yang didapatkan adalah sebesar $1099,27 \mathrm{~cm}^{3}$. Untuk mencari kebutuhan bahan laminasi suatu kapal, dapat dilakukan dengan memasukkan data luas kapal kedalam formula yang sudah dibuat sehingga kita akan mendapatkan jumlah kebutuhan lembar serat non-overlay dan luas serat overlay. Dari data tersebut dapat dicari jumlah kebutuhan resin dan katalis yang diperlukan. Dari data tersebut juga dapat diperkirakan total biaya yang dibutuhkan untuk satu kali laminasi dengan menggunakan rumus yang sudah ada. Dari hasil penelitian, dan pengamatan saat penelitian juga dapat disimpulkan bahwa dari prosedur, tempat, komposisi material, dan keselamatan kerja saat laminasi banyak yang tidak sesuai dengan standar pengerjaan laminasi yang ada.

\section{DAFTAR PUSTAKA}

Anwar K. 2012. Analisis Produksi Kapal Perikanan Berbahan Dasar Kayu dan Fiberglass [Skripsi]. Bogor (ID) : Institut Pertanian Bogor.

Fiberglasssite. 2010. How much resin do i need. [internet]. [diunduh 2014 jul 15]. Tersedia pada http://www.fiberglasssite.com/servlet/the-Learning-Center-cln-How-Much-Resin/Categories. 
Latief PV. 2013. Identifikasi keselamatan kerja pada proses pembuatan perahu fiberglass. [Skripsi]. Bogor (ID): Institut Pertanian Bogor.

Ma'ruf B. 2010. Modernisasi Dan Standarisasi Teknologi Pembangunan Kapal Sephull Berbahan Fibreglass. Surabaya : BPPH-BPPT Institut Teknologi Sepuluh November

McVeagh J, Anmarkrud T, Gulbrandsen O, Ravikumar R, Danielsson P, Gudmundsson A. 2010. Training manual on The Construction of FRPBeach Landing Boat. Rome: FAO.

Michigan Fibreglass. 2010. Tips and repair methods to avoid. [internet]. [diunduh 2014 jul 15]. Tersedia pada :http://www.michiganfibreglass.com/gelcoat.jb/mustreadrepairtips.htm.

Nurcahyadi Moh. 2010. Tekno Ekonomi Pembuatan Perahu Fiberglass Didesa Cikahuripan Kecamatan Cisolok, Sukabumi. [Skripsi]. Bogor : Departemen Pemanfaatan Sumberdaya Perikanan, Institut Pertanian Bogor.

Performance Yacht System. 2010. Choosing The Right Resin - Polyester Resin.[internet]. [diunduh 2014 jul 15]. Tersedia pada : http://www.pyacht.com/evercoat-laminating-resin.htm.

Sari RP. 2010. Nilai Kekuatan Mekanis Material Fiberglass Pada Contoh Uji Kombinasi Matt Dan Roving [Skripsi]. Bogor (ID) : Institut Pertanian Bogor.

Susanto A. 2010. Evaluasi Desain Dan Stabilitas Kapal Penangkap Ikan Di Palabuhanratu (Studi Kasus Kapal Psp 01) [Skripsi]. Bogor (ID) : Institut Pertanian Bogor.

Wave Train. 2011. Fibreglass Boat Building : Cored Lamination. [internet]. [diunduh 2014 jul 15]. Tersedia pada : http://www.wavetrain.net/boats-a-gear/243-fiberglass-boatbuilding-coredlaminates\%5C. 